REVISTA DE DERECHO UNED, NÚM. 27, 2021

\title{
DERECHO DE ACCESO A LOS ELEMENTOS ESENCIALES PARA IMPUGNAR LA LEGALIDAD \\ DE LA DETENCIÓN POLICIAL Y GARANTÍAS CONSTITUCIONALES AFECTADAS
}

\section{RIGHT OF ACCESS TO ESSENTIAL ELEMENTS TO CHALLENGE THE LEGALITY OF POLICE ARREST AND CONSTITUCIONAL GUARANTEES AFFECTED}

\author{
ManUel Hernández IZAGUERRI
}

Doctor en Derecho

Profesor-tutor de la UNED (Centro Asociado de Calatayud)

Sumario. I. Introducción. II. Garantía casos legales que justifican la detención. III. Garantía de información de hechos atribuidos, derechos y razones de su detención. IV. Derecho de acceso a los elementos esenciales para impugnar la legalidad de la detención frente al acceso al atestado en sede policial. IV.1. Acceso al atestado en sede policial. IV.2. Contenido y finalidad del derecho de acceso a los elementos esenciales. IV.3. Momento y forma de ejercer el derecho de acceso a los elementos esenciales en sede policial. IV. 4. Garantías constitucionales afectadas. V. Conclusiones. VI. Bibliografía. VII. Jurisprudencia.

Resumen. Este estudio se centra fundamentalmente en el nuevo derecho de acceso a los elementos esenciales para impugnar la legalidad de la detención policial y en la afección de algunas de las garantías constitucionales relacionadas con él. Las garantías del detenido de carácter penal previstas en el art. 17 de la Constitución Española de 1978 (CE) y desarrolladas fundamentalmente en la Ley de Enjuiciamiento Criminal (LECrim), hasta las reformas de 2015, no se acomodaban plenamente a la normativa más reciente de la 
Unión Europea (UE). Mediante las LLOO 5/2015, de 27 de abril y $13 / 2015$, de 5 de octubre, surgieron algunas discrepancias en la interpretación y aplicación de alguna de ellas, especialmente en relación con el nuevo derecho de acceso a los elementos de las actuaciones esenciales para impugnar la legalidad de la detención frente al acceso al atestado previo a la declaración del detenido en sede policial. Estas situaciones controvertidas han sido atendidas por la Comisión Nacional de Coordinación de Policía judicial (CNCPJ), Fiscalía General del Estado (FGE) y el Tribunal Constitucional (TC).

Palabras clave. Garantías constitucionales, derecho de acceso, elementos esenciales, detención policial, atestado.

Abstract. This study focuses mainly on the new right of access to the essential elements to challenge the legality of police arrest and on the affection of some constitutional guarantees related to it. The guarantees of the criminal arrested provided for in art. 17 Spanish Constitution of 1978 (EC) and developed fundamentally in the Criminal Procedure Law (LECrim), until the 2015 reforms, did not fully comply with the most recent regulations of the European Union (EU). Though LLOO 5/2015, of April 27 and 13/2015, of October 5, some discrepancies arose in the interpretation and application of some of them, especially in relation to the new of access to the elements of the essential actions for challenge the legality of the arrest against access to the report before to the arrestee's statement at the police headquarters. These controversial situations have been addressed by the National Commission for the Coordination of the Judicial Police (CNCPJ), the State Attorney General's Office (FGE) and the Constitutional Court (TC).

Keywords. Constitutional guarantees, right of access, essential elements, police arrest, police report.

Recepción original:1-6-2020

Aceptación original: 4-8-2020 


\section{INTRODUCCIÓN}

Tanto la jurisprudencia del $\mathrm{TC}^{1}$ y la doctrina científica ${ }^{2}$ respecto del art. 17. $1 \mathrm{CE}$ como el TEDH, en relación con el art. $5 \mathrm{CEDH}^{3}$ coinciden en que la libertad protegida es la libertad de movimientos ${ }^{4}$. Esta es la regla general y su privación es la excepción. Los derechos del detenido y las garantías establecidas para protegerlos tienden, a veces, a confundirse o, al menos, a ser tratados como si fueran un mismo concepto ya que, en muchas ocasiones, un derecho constituye a la vez una garantía de otro derecho más amplio. Los derechos previstos en los apartados 1, 2 y 3 del art. $17 \mathrm{CE}$ encajan dentro de las garantías de la libertad física, personal o ambulatoria. El derecho de habeas corpus (art. 17. $4 \mathrm{CE}$ ), es considerado una garantía institucional, tanto por el TC como por la doctrina científica, pero en definitiva es una garantía constitucional.

La doctrina científica, la jurisprudencia nacional e internacional y la normativa europea en esta materia incorporada a nuestro Derecho interno en $2015^{5}$ vienen a corroborar el reforzamiento de las garantías del detenido en el ámbito penal, aunque en mi opinión esta

1 Según reiterada doctrina del TC (SSTC 126/1987, de 16 de julio; 22/1988, de 18 de febrero; 112/1988, de 8 de junio; 61/1990, de 29 de marzo; 120/1990, de 27 de junio, por citar las más recientes) la libertad personal protegida en el art. 17.1 CE es la "libertad física".

2 Entre otros: DÍAZ PICAZO JIMÉNEZ, Luís María: Sistema de Derechos Fundamentales, págs. 269 y 288; GIMENO SENDRA, José Vicente, MORENO CATENA Víctor, ALMAGRO NOSETE, José y CORTÉS DOMÍNGUEZ, Valentín: Derecho Procesal, Tomo II, Proceso Penal, pág. 368; MAGRO SERVET, Vicente: La necesaria nueva regulación de las intervenciones telefónicas a raíz de la jurisprudencia del TEDH, TC y TS; CARRETERO SÁNCHEZ, Adolfo: El verdadero sentido de la detención penal; RODRÍGUEZ RAMOS, Luís, La detención, págs. 12 y 13. GARCÍA MORILLO, Joaquín: El derecho a la libertad personal (detención, privación y restricción de libertad), pág.34.

3 Los derechos establecidos en el artículo 6 de la CDFUE corresponden a los garantizados en el artículo 5 del $\mathrm{CEDH}$, y tienen, con arreglo al apartado 3 del artículo 52 de la Carta, el mismo sentido y alcance. Como consecuencia de ello, las limitaciones que puedan legítimamente establecerse no podrán sobrepasar las permitidas por el CEDH en la propia redacción del artículo 5.

4 En este sentido se pronuncia la STC 120/1990, de 27 de junio, al afirmar que: «la libertad personal protegida por el art. 17.1 CE es la libertad física». También en la STEDH de 8 de junio de 1976 (caso Engel y otros c. Holanda) al afirmar que: «la libertad protegida en el art. 5 del Convenio, es la libertad física (...). Las palabras libertad y seguridad (...) se refieren a la libertad y seguridad físicas».

5 La LO 5/2015, de 27 de abril, por la que se modifican la LECrim y la LOPJ, para transponer la Directivas 2010/64/CE, de 20 de octubre y 2012/13/UE, de 22 de mayo y la LO 13/2015, de 5 de octubre, por la que se modifica la LECrim, incorpora al Derecho interno la Directiva 2013/48/CE, de 22 de octubre, del Parlamento Europeo y del Consejo. 
evolución está inacabada, dado que algunas podrían mejorarse técnicamente, de tal forma que sus garantías constitucionales tengan un desarrollo legal más preciso, claro y sistemático que ayude a todos los operadores jurídicos a aplicar más fácilmente los preceptos procesales penales afectados y evite situaciones controvertidas.

Asimismo, las reformas de la LECrim en 2015 guardan silencio sobre la garantía «casos legales que justifican la detención» frente a la figura del «imputado no detenido en sede policial con asistencia de abogado" ${ }^{6}$, introducida por la Ley 38/2002, de 24 de octubre. El contenido del derecho de información de las razones motivadoras de la detención ha sido fijado por el TC al analizar el nuevo derecho de acceso a los elementos de las actuaciones esenciales para impugnar la legalidad de la detención [art. 520. 2. d) LECrim] introducido por la LO 5/2015, de 27 de abril; no obstante, tampoco han determinado con claridad dicho derecho de acceso a los elementos esenciales frente a las solicitudes de acceso pleno al atestado previo a la declaración del detenido en sede policial, lo que ha reabierto algunos conflictos entre abogados y miembros de la Policía judicial. Todo lo cual se aborda en este trabajo, teniendo en cuenta la doctrina científica, la jurisprudencia del TC y los criterios de la FGE y CNCPJ.

\section{GARANTÍA CASOS LEGALES QUE JUSTIFICAN LA DETENCIÓN}

En el art. 17. $1 \mathrm{CE}$ está prevista la garantía denominada «reserva legal» que tiene dos vertientes o manifestaciones (casos y forma legal de privar a una persona de su libertad ambulatoria), dado que «nadie puede ser privado de su libertad, sino con la observancia de lo establecido en este artículo y en los casos y en la forma previstos en la ley». De esta manera, la ley se presenta como el único instrumento jurídico que ofrece las máximas garantías. La predeterminación de los casos y la forma de la privación de la libertad responde a las exigencias lógicas del principio de seguridad jurídica, dado que todo ciudadano necesita conocer de antemano qué conductas pueden hacerle perder su libertad ambulatoria. El art. $5 \mathrm{CEDH}^{7}$ establece los casos legales que permiten la privación de la libertad de

6 «investigado» desde la LO 13/2015, de 5 de octubre.

7 Art. 5. 1 CEDH. 1. Toda persona tiene derecho a la libertad y a la seguridad. Nadie puede ser privado de su libertad, salvo en los casos siguientes y con arreglo al procedimiento establecido por la ley:

a) Si ha sido privado de libertad legalmente en virtud de una sentencia dictada por un tribunal competente; 
una persona, entre los que se encuentran los previstos en nuestro ordenamiento jurídico.

La detención constitucional y legal de una persona puede revestir diferentes modalidades según su finalidad o carácter: administrativa, civil o penal, dado que la literalidad de la expresión «privado de libertad» del art. 17. 1 CE es lo suficientemente amplia como para acoger no solo al detenido preventivo o al preso por causa penal (art. 17. 2 y $4 \mathrm{CE}$ ), sino también a todas aquellas situaciones fácticas que limiten la libertad ambulatoria en los ámbitos civil ${ }^{8}$ o administrativo ${ }^{9}$, tanto si la privación de libertad va dirigida a mayores o menores de edad y si procede de autoridades o funcionarios públicos como de particulares. Por tanto, podemos decir que la privación de la libertad ambulatoria es el género (art. 17. 1 CE), mientras que la detención preventiva es la especie (art. 17. $2 \mathrm{CE}$ ).

La garantía «casos legales que justifican la detención» en el ámbito penal con desarrollo legal (arts. 490 y ss. de la LECrim) interviene ex ante, de tal modo que la Policía judicial deberá respetarla antes de adoptar dicha medida, la cual se encuentra en el grupo de garantías que pretenden asegurar la libertad ambulatoria, dado que únicamente los casos legales habilitan su privación. El art. 492 LECrim regula conjuntamente los supuestos habilitantes que obligan a detener en el ámbito penal, tanto a la Autoridad (entiéndase ju-

b) Si ha sido detenido o privado de libertad, conforme a derecho, por desobediencia a una orden judicial o para asegurar el cumplimiento de una obligación establecida por la ley;

c) Si ha sido detenido y privado de libertad, conforme a derecho, para hacerle comparecer ante la autoridad judicial competente, cuando existan indicios racionales de que ha cometido una infracción o cuando se estime necesario para impedirle que cometa una infracción o que huya después de haberla cometido;

d) Si se trata de la privación de libertad de un menor en virtud de una orden legalmente acordada con el fin de vigilar su educación o de su detención, conforme a derecho, con el fin de hacerle comparecer ante la autoridad competente;

e) Si se trata de la privación de libertad, conforme a derecho, de una persona susceptible de propagar una enfermedad contagiosa, de en enajenado, de un alcohólico, de un toxicómano o de un vagabundo;

f) Si se trata de la detención o de la privación de libertad, conforme a derecho, de una persona para impedir su entrada ilegal en el territorio o contra la cual esté en curso un procedimiento de expulsión o extradición».

${ }^{8}$ La detención preventiva o privación de libertad previa de enfermos mentales para el internamiento no voluntario en un centro psiquiátrico, conforme con el art. 5. 1. e) CEDH, con la CE y el art. 763 LEC y la de enfermos contagiosos para su ingreso hospitalario no voluntario, conforme a la Ley 14/1986, de 25 de abril, General de Sanidad (art. 26. 1) y la LO 3/1986, de 14 de abril, de Medidas Especiales en Materia de Salud Pública.

9 Detención preventiva previa a la expulsión de un extranjero (SSTC 21/1996, de 12 de febrero; 66/1996, de 16 de abril, y 86/1996, de 21 de mayo).

(C) UNED. Revista de Derecho UNED, núm. 27, 2021 
dicial, fiscal o administrativa) como al agente de la Policía judicial. Asimismo, dicho precepto legal no distingue entre detenciones judiciales ni detenciones policiales o las acordadas por el Ministerio fiscal. Todos los casos que obligan a detener previstos en dicho precepto procesal penal pueden corresponder con las detenciones judiciales, aunque la Policía judicial las practique si lo ordena la Autoridad judicial. La Policía judicial está habilitada para practicar todos los supuestos de detención previstos en dicho artículo, pero no lo está para acordarlos. A la Policía judicial solo le está permitida la detención preventiva en la mayoría de los supuestos regulados en el apartado $1^{\circ}$ del art. 492 LECrim (se remite a los casos del art. 490 LECrim) y el previsto en el apartado $4^{\circ}$. La configuración de la detención preventiva de carácter penal nos indica que en esta medida deben concurrir los dos requisitos de una medida cautelar; no obstante, identificar al delincuente y detener a los presuntos responsables del delito forma parte de las primeras diligencias que define el art. 13 LECrim. En la mayoría de los casos, estas son realizadas por la Policía judicial, bien a iniciativa propia, bien por denuncia, cuando no se existe causa judicial abierta, por lo que la detención policial se produce en esta fase preprocesal, pendiente en su caso de confirmación por Autoridad judicial. De igual modo, la detención acordada por el Ministerio fiscal en asuntos penales (estos no estarán todavía judicializados) será considerada preventiva, porque este no está facultado para adoptar medidas cautelares ${ }^{10}$ y la decisión sobre la situación personal del detenido puesto a disposición judicial recae finalmente en la Autoridad judicial.

El art. 292 LECrim hace referencia a los indicios del delito que deben ser recogidos por los funcionarios de la Policía judicial en las diligencias que practiquen (también en las primeras diligencias), mientras que el apartado $4^{\circ}$ del art. 492 LECrim exige para detener a una persona la existencia de «motivos racionalmente bastantes» para creer en la existencia de un hecho que revista caracteres de delito y de su participación en él, pero la jurisprudencia utiliza indistintamente indicios y motivos, hasta el punto de confundirse ${ }^{11}$. Los

10 Artículo quinto de la Ley 50/1981, de 30 de diciembre, por el que se regula el Estatuto Orgánico del Ministerio Fiscal (EOMF).

${ }^{11}$ El TC utiliza indistintamente dichos términos (indicios o motivos) como si del mismo concepto se tratara. Según el TC, el fumus boni iuris o apariencia de buen derecho se basa en la concurrencia de indicios racionalmente bastantes para creer que se ha producido un delito, y bastantes para creer que una persona concreta tuvo participación en él. La STS 626/2007, de 5 de julio, es un claro ejemplo de la utilización de ambos términos de forma indistinta, ya que unas veces se refiere a indicios y otras alude a motivos. 
indicios son superiores a las meras sospechas o conjeturas que constituyan noticia razonable de la existencia del delito que se investigue y su presunta participación de determinadas personas. Las sospechas o meras conjeturas no son suficientes ni justifican la detención de una persona, por lo que esta no sería ajustada a derecho. Aunque el art. 492. $4^{\circ}$ LECrim $^{12}$ exige que concurra la existencia de «motivos racionales bastantes», puesto que aquel no refiere explícitamente a la existencia de indicios racionales bastantes, lo cierto es que si estos existen no cabe duda que habrá motivos racionalmente bastantes para detener. Este concepto jurídico («motivos racionales bastantes») es de suma importancia para la correcta aplicación de las garantías: "casos legales que justifican la detención» desarrollada en el art. 492. $4^{\circ}$ LECrim (para el ámbito penal), información de los hechos atribuidos, derechos y las razones de su detención y, defensa (personal o autodefensa y técnica por medio de abogado), ya que si no existieran aquellos no estaría justificada la detención al no concurrir razones para ello, el derecho de defensa podría verse afectado, y en su caso, procedería su citación como investigado no detenido en sede policial.

Para DE HOYOS SANCHO ambos (indicios y motivos) son expresiones similares en cuanto a la necesidad implícita de que ambas existan ${ }^{13}$. Los motivos para detener a una persona se basan en indicios, dado que estos no constituyen prueba, tanto en fase policial como de instrucción judicial de la causa, salvo que se hubiese preconstituido una prueba anticipada ${ }^{14}$.

De lo anterior se puede inferir que los «motivos racionalmente bastantes» del art. 492. $4^{\circ}$ LECrim se configuran como un concepto jurídico indeterminado con un contenido difícil de concreción $a$ priori. Posiblemente este supuesto legal habilitante de la detención preventiva de carácter penal sea el más utilizado por la Policía judicial, porque el límite punitivo de 3 años de prisión a que se refiere aquel corresponde con la mayoría de los delitos menos graves pre-

12 El art. 492 LECrim señala que: «La Autoridad o agente de Policía Judicial tendrá obligación de detener: $4 .^{\circ}$ Al que estuviere en el caso del número anterior, aunque todavía no se hallase procesado, con tal que concurran las dos circunstancias siguientes: 1 ${ }^{\mathrm{a}}$. Que la Autoridad o agente tenga motivos racionalmente bastantes para creer en la existencia de un hecho que presente los caracteres de delito. $2^{a}$. Que los tenga también bastantes para creer que la persona a quien intente detener tuvo participación en él».

13 DE HOYOS SANCHO, Montserrat: La detención por delito, pág. 218.

${ }^{14}$ Con carácter general, la prueba se practica en el plenario o juicio oral al someterlos a los principios de contradicción, publicidad, oralidad e inmediación, la cual será capaz de vencer la presunción de inocencia (STS 10/2010, de 28 de enero). 
vistos en el CP 1995. La detención de una persona en el ámbito penal con base en este precepto legal se debe sustentar en indicios y estos, a su vez, en hechos concretos contrastados; por tanto, ambos constituyen los motivos a los que se refiere la LECrim. Sobre la base de los datos objetivos se ha de llevar a cabo una valoración acerca de si los hechos merecen la consideración de bastantes para permitir la actuación preprocesal. En consecuencia debe concurrir un nexo causal lógico entre los motivos, la calificación jurídica de los hechos delictivos y la participación en los mismos de la persona a quien se va a detener. La regulación legal exige literalmente una pluralidad de motivos racionales, por lo que un único motivo o incluso varios podrían ser insuficientes si por sí solos no fueran racionalmente bastantes para llegar a la convicción de que el sujeto tuvo participación en la infracción penal investigada.

El TC, después de analizar el art. 492 LECrim ${ }^{15}$ exige para la adopción de medidas cautelares penales, referida a la detención preventiva, la concurrencia de dos presupuestos básicos (fumus boni iuris y periculum in mora $)^{16}$. Asimismo, existen otros elementos diferentes a los propios de toda medida cautelar que los agentes policiales deberán tener en consideración para proceder a la detención preventiva si alguno de ellos concurre, aunque falte el riesgo de incomparecencia ante la Autoridad judicial. Los riesgos o peligros que deben valorarse para acordar, practicar o prolongar la detención policial están íntimamente relacionados con la práctica de las primeras diligencias (art. 13 LECrim) o las diligencias de prevención (arts. 282 y 284 LECrim) y, posteriormente, tiene similar reflejo cuando el Juez instructor acuerde la prisión provisional.

Por otro lado, el art. 771. $2^{\mathrm{a}}$ ) LECrim, introducido por la Ley $38 / 2002$, de 24 de octubre, creó, por primera vez en nuestro sistema procesal, la figura preprocesal del «imputado no detenido» en sede policial («investigado» desde la LO 13/2015, de 5 de octubre), tanto en los delitos enjuiciados en el procedimiento abreviado, como en los juicios rápidos para determinados delitos y, relajó la obligación

15 El ATC 94/1990, 26 de febrero, (Sala $2^{\text {a }}$ ) señala que: «Analizando los preceptos correspondientes, especialmente el art. 492 LECrim, salta a la vista que nuestro ordenamiento configura la detención preventiva como una medida cautelar...».

16 a) El fumus boni iuris, o "apariencia de buen derecho", que se basa en la concurrencia de indicios racionalmente bastantes para creer que se ha producido un delito, y bastantes para creer que una persona concreta tuvo participación en él.

b) El periculum in mora, o "peligro en la demora", que se fundamenta en la existencia razonada de una situación de riesgo, que podría poner en peligro el correcto desarrollo del proceso, si se retrasa la adopción de la medida cautelar. 
de detención de los agentes de la Policía judicial, de tal forma que habrá que determinar cuándo la Policía judicial debe adoptar esta medida («investigado no detenido») y, por tanto, no está obligado a detener. El primer presupuesto de toda medida cautelar no puede faltar, puesto que es de carácter sustancial o material (hecho delictivo que se imputa al presunto partícipe en el mismo), de tal forma que el segundo de los presupuestos (periculum in mora) podría ser en principio, decisivo (aunque no único y absoluto en todo caso), bien para citar al investigado en sede policial y no proceder a su detención, bien para proceder a su detención preventiva. La Policía judicial, si no procede a la detención del presunto partícipe en los delitos previstos en el art. 757 LECrim $^{17}$, deberá respetar las garantías del investigado, ya que este debe ser instruido de algunos de los derechos del detenido previstos en los apartados a), b), c) y e) del art. 520. 2 LECrim. Los delitos por los que podrá la Policía judicial investigar sin detención no acogerá a todos los que recoge el art. 757 LECrim, esto es, a los castigados con pena privativa de libertad no superior a nueve años.

El art. 492. $4^{\circ}$ LECrim obliga a los agentes policiales a la detención del no procesado cuando se den los dos requisitos que dicho apartado refiere por los delitos castigados con pena de prisión hasta de 3 años. Por tanto, este será el límite que los agentes de la Policía judicial deberán considerar para proceder a la investigación sin detención, siempre y cuando no concurra el riesgo de incomparecencia a la Autoridad judicial. En mi opinión, si los agentes de la Policía judicial no procedieran a la detención preventiva de una persona y le citaran como investigado no detenido, en virtud del art. 771. $2^{\mathrm{a}}$ ) LECrim, debería ser porque: a) no hay peligro de no comparecencia ante la Autoridad judicial (hay domicilio conocido, el delito imputado es de pena no superior a 3 años, da fianza bastante a juicio de los agentes); b) no existe tampoco riesgo de ocultación u obstrucción a la investigación o a la justicia, porque los efectos, objetos o instrumentos del delito se han recuperado, o ello carece de interés según el estado de la investigación; c) ni existe riesgo para la vida o integridad de las personas, dado que las víctimas objeto de violencia doméstica o de género están perfectamente protegidas o el presunto partícipe en este tipo de hechos delictivos no se encuentra entre el grupo de personas con riesgo de reincidencia. Asimismo, otro criterio para citarle como investigado policial no detenido en sede policial podría encontrarse en aquellos casos en los que existe racio-

17 Estos delitos siguen la tramitación del procedimiento abreviado. 
nalmente algún indicio de su participación en el delito investigado, pero no «bastantes» tal y como prevé el art. 492. $4^{\circ} .2^{\mathrm{a}}$.) LECrim.

En definitiva, el detenido o su abogado pueden verificar si está indicada la detención preventiva en sede policial mediante la solicitud de habeas corpus (art. 17. $4 \mathrm{CE}$ ) y solicitando antes el nuevo derecho de acceso a los elementos esenciales para impugnar la legalidad de la detención, pero una diferencia fundamental está en que el Juez de instrucción no interviene en el ejercicio de este último si este acceso se pretende en sede policial, lo cual no impedirá instar el primero. La detención penal no es un acto discrecional, sino minuciosamente reglado e instrumental de la investigación criminal, excepcional, temporal, provisional y que ha de respetar los principios de legalidad, subsidiaridad, proporcionalidad y necesidad, pero su regulación actual exige a la Policía judicial en la mayoría de los casos una labor interpretativa de excesiva complejidad para acordarla sin lesionar esta garantía constitucional («casos legales que justifican la detención»). Esta garantía queda reforzada mediante este nuevo derecho de acceso a los elementos esenciales, aunque a posteriori, dado que permitirá al detenido o a su abogado comprobar si aquella se respetó ex ante y, en su caso, impugnarla para que cese dicha medida y se restituya la libertad ambulatoria, pero la actual configuración de los arts. 492 y $771.2^{\mathrm{a}}$ LECrim, no favorecen la labor integradora e interpretativa necesaria para su fácil aplicación, por lo que de lege ferenda el legislador debería establecer claramente los casos en los que en sede policial procedería acordarse la detención penal del investigado y los casos en los que resultaría procedente llamarle como investigado no detenido, ambos a iniciativa de la Policía judicial.

\section{GARANTÍA DE INFORMACIÓN DE HECHOS ATRIBUIDOS, DERECHOS Y RAZONES DE SU DETENCIÓN}

A nivel internacional resultan significativos los arts. 9. 2 PIDCP y 5. $2 \mathrm{CEDH}$, que reconocen a toda persona detenida el derecho de información de: «los motivos o razones de su detención y de cualquier acusación contra él», pero curiosamente guardan silencio sobre si el detenido debe ser informado de sus derechos, así como tampoco se prevé el derecho de asistencia letrada en las detenciones preventivas policiales. De ahí que la CE sea más generosa que estas normas internacionales, como ha señalado el TC en numerosas ocasiones ${ }^{18}$.

18 STC, Pleno, 196/1987, de 11 de diciembre, recordada entre otras por la STC 252/1994, de 19 de septiembre. 
Asimismo, el art. 6. 2 de la Directiva 2012/13/UE, de 22 de mayo, con apoyo en los arts. 6 y 47 CDFUE dispone que: «Los Estados miembros garantizarán que toda persona sospechosa o acusada que sea detenida o privada de libertad sea informada de los motivos de su detención o privación de libertad, incluida la infracción penal que se sospecha que ha cometido o de la que se le acusa».

Como recuerda el $\mathrm{TC}^{19}$, el conjunto de motivos que sustenta la decisión de detener conforma la sospecha policial, y, en este sentido, el control sobre su razonabilidad y consistencia es uno de los elementos esenciales de la posibilidad de salvaguardia frente a detenciones arbitrarias ${ }^{20}$. El TEDH ha señalado reiteradamente que, en el contexto de las detenciones preventivas de naturaleza penal, los motivos que sustentan la privación de libertad constituyen un factor relevante para determinar si una detención es o no arbitraria ${ }^{21}$.

Este derecho fundamental del detenido a la información, según el art. 17.3 CE, afecta a un doble contenido "sus derechos y razones de su detención» el cual es desarrollado por el art. 520.2 LECrim que amplía dicha información a los hechos atribuidos, por tanto, su triple contenido se extiende a "...los hechos que se le atribuyan y las razones motivadoras de su privación de libertad, así como de los derechos que le asisten...». Esta información debe realizarse por la Policía judicial, la Autoridad judicial o el Ministerio fiscal que lleve a cabo la detención de "forma inmediata» y de "modo comprensible», ya que necesita comprender la situación de iure en que se encuentra, lo cual ha sido confirmado por la STC 21/2018, de 5 de marzo.

Las razones o motivos de la detención tienen un contenido distinto de la información sobre los hechos investigados, según se desprende del art. 17. $3 \mathrm{CE}$ que regula el derecho a la libertad personal, física o ambulatoria, mientras que el derecho a conocer la acusación se proclama en el art. 24. 2 CE como garantía del derecho de defensa en el proceso judicial. La información sobre las razones de la detención es una consecuencia del derecho de la libertad reconocido en el art. 17. $1 \mathrm{CE}$, puesto que si nadie puede ser privado de su libertad sino en virtud de los casos previstos en esta norma constitucional o en la ley, es lógico que se le informe sobre la concurrencia del supuesto que determina adoptar dicha medida. Ahora bien, ni la CE ni las últimas reformas de la LECrim en 2015 delimitan el contenido de

19 STC 21/2018, de 5 de junio.

20 SSTEDH de 30 de agosto de 1990, caso Fox, Campbell and Hartley c. Reino Unido, y de 28 de octubre de 1994, caso Murray c. Reino Unido.

21 Por todas, STEDH de la Gran Sala, de 9 de julio de 2009, dictada en el caso Mooren c. Alemania.

(C) UNED. Revista de Derecho UNED, núm. 27, 2021 
las razones motivadoras de su detención; no obstante, el TC determina que «...la información que debe ser facilitada solo es suficiente si tiene un triple contenido:...»), por lo que este establece una doctrina específica sobre como es el alcance del derecho a conocer «las razones motivadoras» de la detención policial, el correlativo deber de información que recae sobre los poderes públicos, y su conexión instrumental con el recientemente reconocido derecho de acceso a las actuaciones durante la detención y el propio derecho de asistencia letrada al detenido (art. 17. $3 \mathrm{CE})^{22}$.

MARTÍNEZ PARDO señala que con esta información se entiende cumplido el presupuesto periculum in mora, es decir, los antecedentes del detenido o las circunstancias que hagan presumir al policía que el detenido no comparecerá ante la Autoridad judicial cuando fuere llamado (art 492. $3^{\circ}$ LECrim). Según este autor, las razones de la detención se refieren a las causas o motivos legales que han determinado el acuerdo de privación de libertad (arts. 490, 492, 495 LECrim) o que han motivado la detención ${ }^{23}$. RODRÍGUEZ RAMOS señala que los motivos o fundamentos de la privación de libertad, se refieren al precepto legal por el que se le detiene. GIMENO SEN$\mathrm{DRA}^{24}$ añade que la calificación realizada por los agentes de la Policía judicial no puede vincular en modo alguno al órgano jurisdiccional. En este sentido se ha pronunciado el $\mathrm{TC}^{25}$ en algunas ocasiones.

La FGE ${ }^{26}$ se refiere a que la primera información que debe facilitarse al detenido, por escrito, esto es, la relativa a los hechos y a las razones que motivan la detención y añade que «La información sobre los hechos incluye su calificación jurídica provisional». En sentido si-

22 STC 21/2018, de 5 de octubre. "...la información que debe ser facilitada solo es suficiente si tiene un triple contenido: se ha de extender a los hechos atribuidos, a las razones motivadoras de la privación de libertad y a los derechos que, durante su detención, definen su estatuto personal. La información que la policía debe facilitar al detenido se extiende, por tanto, a los motivos jurídicos y fácticos de la detención; es decir, no sólo debe identificar y calificar provisionalmente la infracción penal que se sospecha ha cometido la persona detenida, sino también los datos objetivos que permiten establecer una conexión lógica entre la conducta del sospechoso y el hecho investigado. No es suficiente, por tanto, con hacer referencia al hecho investigado, su lugar y fecha de comisión y su calificación jurídica provisional, sino que la información policial ha de poner también de manifiesto el fundamento de la conexión subjetiva y objetiva del detenido con el hecho ilícito que justifica la detención».

${ }_{23}$ MARTÍNEZ PARDO, V. J.: La detención y el internamiento de extranjeros, pág. 319.

24 GIMENO SENDRA, J. V.: Derecho Procesal, por GIMENO SENDRA, J. V., MORENO CATENA, V., ALMAGRO NOSETE, J., CORTÉS DOMÍNGUEZ, V.: El Proceso Penal, pág. 367.

25 SSTC 96/1980, de 1 de abril y 105/1983, de 23 de noviembre.

26 Circular de la FGE 3/2018, de 1 de junio. 
milar, el TS indica que: «la información de los hechos que motivan la detención será un requisito sine qua non para el ejercicio del derecho de defensa y la información acerca de las razones que han motivado la privación de libertad, implica precisar el precepto que en el caso concreto justifica la detención».

En mi opinión, la expresión «razones motivadoras de la detención» (el por qué de la detención) debería contener tres elementos: a) la base fáctica que abarcan o se refieren a que los hechos investigados que quedan subsumidos en la norma penal infringida; b) la calificación jurídica y el grado de participación (elemento penal) y, c) el precepto legal que obliga a la detención (elemento procesal). El acceso a los elementos esenciales en sede policial debe servir para cumplir entre otras funciones que: el detenido o su abogado puedan comprobar, contrastar o verificar si el atestado instruido hasta ese momento contiene o corresponde con la información facilitada sobre los hechos atribuidos, derechos y las razones motivadoras de su detención; y si la detención preventiva policial estaba indicada legalmente o si por el contrario era procedente la toma de declaración como investigado no detenido.

El art. 17. $3 \mathrm{CE}$ y su desarrollo legal señalan que la «forma inmediata» de información se refiere a los hechos atribuidos, derechos y razones de la detención, quedando excluida de esa inmediatez, al menos teóricamente, el ejercicio efectivo o real de los derechos del detenido. A priori, según la previsión constitucional, los agentes de la Policía judicial no parece que estén obligados a garantizar la inmediatez del ejercicio de los derechos del detenido, aunque dado que la detención debe durar el menor tiempo posible («estrictamente necesario»), el ejercicio efectivo o real de los derechos del detenido deberán materializarse durante la detención y lo antes posible, aunque no necesariamente de "forma inmediata", como sí se explicita sobre el derecho de información propiamente dicho. Además, puede ocurrir que el detenido no decida ipso facto si ejerce o no sus derechos, ya que tampoco el detenido está obligado a decidir de forma inmediata qué derecho ejercitar entre el catálogo de derechos de los que le ha sido informado, de tal forma que él puede solicitar a los agentes su ejercicio en cualquier momento de la detención. En cambio, el ejercicio de otros derechos del detenido deben llevarse a cabo «sin demora injustificada» [art. 520. 2.c), e), f) LECrim $]^{27}$, pero tampoco de «forma inmediata» en todo caso. El

27 Art.520. 2 LECrim . «c) Derecho a designar abogado, sin perjuicio de lo dispuesto en el apartado 1.a) del artículo 527 y a ser asistido por él sin demora injustificada. En caso de que, debido a la lejanía geográfica no sea posible de inmediato la 
nuevo art. 520. 5 LECrim obliga a la comunicar «inmediatamente» al Colegio de abogados la detención policial ${ }^{28}$ y reduce el plazo de presentación del abogado (designado o de oficio) en dependencias policiales (de 8 horas a 3 horas), quien deberá comparecer «con la máxima premura» o "a la mayor brevedad» dentro de ese plazo máximo desde que recibió el encargo, pero no de forma inmediata necesariamente o en todo caso.

Para que el detenido conozca esa información se exige constitucionalmente que sea facilitada de «modo comprensible», es decir, que se exprese con claridad y sin términos técnicos, de tal manera que los entienda quien los recibe, independientemente de su grado de instrucción o formación, nacionalidad o cualquier otra circunstancia. Si la persona detenida no comprende la lengua oficial del Estado, o las cooficiales en las CCAA, dicha información se llevará a cabo por medio de intérprete, puesto que si no fuera así, el ejercicio del derecho de información del detenido no sería posible materializarlo como exige el art. 17. 3 CE. El art. 520. 2 bis LECrim, introducido por la LO 5/2015, de 27 de abril, reforzó el modo comprensible de la garantía de información, dado que obliga a adaptarla a su edad, grado de madurez, discapacidad y cualquier otra circunstancia personal ${ }^{29}$.

Asimismo, el art. 17. 3 CE no explicita que tal información deba hacerse por escrito, ni considera imprescindible que se realice de esta forma pudiendo realizarse oral, tal y como el TC lo había declarado $^{30}$; no obstante, para ello hubo que esperar a la LO 5/2015, de 27 de abril, que modificó el art. 520.2 LECrim ${ }^{31}$ y además amplió el ca-

asistencia de letrado, se facilitará al detenido comunicación telefónica o por videoconferencia con aquél, salvo que dicha comunicación sea imposible.

e) Derecho a que se ponga en conocimiento del familiar o persona que desee, sin demora injustificada, su privación de libertad y el lugar de custodia en que se halle en cada momento. Los extranjeros tendrán derecho a que las circunstancias anteriores se comuniquen a la oficina consular de su país.

f) Derecho a comunicarse telefónicamente, sin demora injustificada, con un tercero de su elección. Esta comunicación se celebrará en presencia de un funcionario de policía o, en su caso, del funcionario que designen el juez o el fiscal, sin perjuicio de lo dispuesto en el artículo $527 »$.

28 Reformado por la LO 5/2015, de 27 de abril.

29 Art. 520.2 bis LECrim. «La información a que se refiere el apartado anterior se facilitará en un lenguaje comprensible y que resulte accesible al destinatario. A estos efectos se adaptará la información a su edad, grado de madurez, discapacidad y cualquier otra circunstancia personal de la que pueda derivar una limitación de la capacidad para entender el alcance de la información que se le facilita».

${ }^{30}$ STS 6938/1996, de 5 de diciembre, y SAP de Guipúzcoa de 1 de julio de 2000, rec. 3019/2000.

31 A partir de esta reforma: «Toda persona detenida o presa será informada por escrito, en un lenguaje sencillo y accesible, en una lengua que comprenda y de 
tálogo de derechos del detenido penal. Como indica FERNÁNDEZ NIETO $^{32}$, la jurisprudencia del TC plasmada en la STC 21/2018, de 5 marzo y otras anteriores como la STC 13/2017, de 30 de enero, han supuesto un precedente importante en formular el contenido del derecho fundamental del detenido a la información sobre expediente judicial, sobre las razones de su detención, y la fase de la investigación policial como trasunto a la apertura de la vía judicial.

El último inciso del art. 520. 2 LECrim prevé ex novo que: "En todos los casos se permitirá al detenido conservar en su poder la declaración escrita de derechos durante todo el tiempo de la detención». El legislador de 2015 debería haber aprovechado esta reforma para explicitar que esta declaración escrita se extendiese al triple contenido de la garantía constitucional de información desarrollada en el art. 520. 2 LECrim, esto es, "...hechos atribuidos, razones de su detención y derechos que le asisten,...» y no solo a estos últimos como se desprende de su literalidad, por varios motivos:

a) La Directiva 2010/64/UE, de 20 de octubre (art. 2.8) pretende garantizar la interpretación «...en particular, que el sospechoso o acusado en un proceso penal tenga conocimiento de los cargos que se le imputan», además, dado que tanto la detención policial o fiscal como la prisión acordada por la Autoridad judicial son medidas de privación de libertad, su plasmación escrita debe constituir documento esencial que aquellos (detenido o preso) deberían conocer de oficio, bien directamente en castellano o lengua de la Comunidad Autónoma, bien por la vía de la interpretación (art. 2. 8) o de la traducción (art. 3. 2) para los extranjeros o quienes no conozcan la lengua oficial de España. Esto mismo es predicable para los detenidos que no requieran intérprete, dado que el art. 520. 2 LECrim se aplicable «En todos los casos... ».

b) El anexo I de la Directiva 2012/13/UE, de 22 de mayo, establece un modelo indicativo de declaración de derechos para ayudar a las autoridades competentes, el cual pueden modificarlo a fin de armonizarlo con las normas nacionales aplicables y añadir otra información útil. En España esta información corresponde no solo con los derechos sino que se amplía a las razones de su detención ex art. 17. $3 \mathrm{CE}$.

forma inmediata, de los hechos que se le atribuyan y las razones motivadoras de su privación de libertad, así como de los derechos que le asisten...».

${ }^{32}$ FERNÁNDEZ NIETO, Josefa: El acceso a los atestados policiales: a vueltas con las garantías de defensa en el proceso penal español, págs.41 y 42. 
c) Si esta copia de declaración de derechos que guarda el detenido en poder durante toda la detención solo contiene estos últimos y no consta en ella la triple información que indica el TC, el detenido debería ejercitar su derecho al acceso a los elementos esenciales previstos en el art. 520. 2. d) LECrim para conocer o consultar las mismas, de tal forma que su derecho de información no quede supeditado al ejercicio de aquel derecho de acceso, y se respete la «forma inmediata» de conocerlas tal y como prevé el art. 17.3 CE.

d) Como ha indicado el $\mathrm{TC}^{33}$ «La facultad de acceso reconocida por la ley tiene como finalidad facilitar la posibilidad de contrastar objetivamente la veracidad y consistencia de la información recibida». Además, si no se hubiera facilitado con inmediatez la información de las razones motivadoras de la detención, dicho acceso también serviría para suplir o subsanar dicho defecto.

e) Como resume la FGE sobre la reciente doctrina derivada de la STC 21/2018: «la información sobre los hechos y las razones que han motivado la detención ha de formalizarse en un documento que ha de entregarse al detenido, admitiéndose que sea el mismo en el que se recoja la información sobre los derechos del detenido, debiendo dejarse constancia en el atestado de la fecha y hora en que se ha producido dicha información; debe facilitarse de forma inmediata, y en todo caso, antes del primer interrogatorio por parte de la policía; y debe ser suficiente, lo que sólo se cumple si tiene un triple contenido: se ha de extender a los hechos atribuidos, a las razones motivadoras de la privación de libertad y a los derechos que, durante su detención, definen su estatuto personal».

f) La habitual práctica forense en sede policial es más favorable que la literalidad del segundo inciso del art. 520. 2 LECrim, dado que la copia entregada al detenido no suele quedarse tan solo en la entrega de la copia relativa al catálogo de derechos sobre los que ha sido informado inmediatamente, dado que esta suele recoger también la información sobre los hechos atribuidos, derechos y las razones motivadoras de la detención como se desprende de los criterios de la CNCPJ dictados en 2017. Esta prescribe como modelo una diligencia de detención e información de derechos y de los elementos esenciales de las

33 STC 21/2018, de 5 de marzo. 
actuaciones para impugnar la legalidad de la detención ${ }^{34}$. Esto pone de manifiesto el defecto técnico que debería ser subsanado para evitar situaciones polémicas e indeseables por una aplicación literal y estricta de dicho precepto legal.

En definitiva, este triple contenido del derecho de información del detenido o del privado de libertad debe conectarse con los presupuestos que justifican la detención (art. 492 LECrim, para las detenciones practicadas por la autoridad o agente de la Policía judicial), esto es, la garantía "casos legales que justifican la detención» y, con el derecho de defensa del detenido (autodefensa y defensa técnica), dada la conexión o relación existente entre ellas ${ }^{35}$.

\section{DERECHO DE ACCESO A LOS ELEMENTOS ESENCIALES PARA IMPUGNAR LA LEGALIDAD DE LA DETENCIÓN FRENTE AL ACCESO AL ATESTADO EN SEDE POLICIAL}

Este nuevo derecho-garantía afecta a los derechos-garantías relativos a: los casos legales que justifican la detención y la forma legal de acordar, practicar o prolongarla; la información de los hechos atribuidos, derechos y las razones de la detención, la defensa personal o autodefensa y técnica mediante la asistencia de abogado ${ }^{36}$, plazo de duración de la detención y habeas corpus ${ }^{37}$. El aspecto más

34 La CNCPJ indica que: "Se permitirá al detenido conservar en su poder la declaración escrita de derechos durante todo el tiempo de la detención, de forma que sea compatible con la seguridad física de su persona durante la estancia en dependencias policiales. Cuando tal compatibilidad no permita que el detenido conserve en su poder el escrito de declaración de derechos, éste permanecerá a su disposición, mientras dure la detención, junto a sus efectos personales». El modelo de declaración escrita de derecho que propone es: "DILIGENCIA DE DETENCIÓN E INFORMACION DE DERECHOS Y DE LOS ELEMENTOS ESENCIALES DE LAS ACTUACIONES PARA IMPUGNAR LA DETENCIÓN».

35 Véase el apartado IV. 4. Garantías constitucionales afectadas.

${ }^{36} \mathrm{El}$ abogado es el alter ego del detenido que opera durante la detención y según ha declarado el TC (SSTC, Pleno, 21/1997, de 10 de febrero; 196/1987, de 11 de diciembre, y 252/1994, de 19 de septiembre) sus finalidades consisten en:

«a) asegurar, con su presencia personal, que los derechos constitucionales del detenido sean respetados, que este no sufra coacción o trato incompatible con su dignidad y libertad de declaración.

b) comprobar, una vez realizados y concluidos los interrogatorios, la fidelidad de lo trascrito en el acta de declaración que se le presenta a la firma.

c) asesoramiento técnico sobre la conducta a observar en los interrogatorios, incluida la de guardar silencio, así como la presencia activa del letrado en estos interrogatorios».

${ }_{37}$ La finalidad del habeas corpus es "producir la inmediata puesta a disposición judicial de cualquier persona detenida ilegalmente» conforme al art. 17. $4 \mathrm{CE}$ y art. 1

(c) UNED. Revista de Derecho UNED, núm. 27, 2021 
controvertido surgido de las reformas de la LECrim en 2015 está relacionado con el contenido, momento y forma de llevar a cabo este nuevo derecho frente al acceso al atestado en sede policial por el detenido o su abogado, dado que los «elementos esenciales» son un concepto jurídico indeterminado.

\section{IV.1. ACCESO AL ATESTADO EN SEDE POLICIAL}

La Ley 38/2002, de 24 de octubre, vino a zanjar la polémica cuestión sobre si el abogado podía o no tener acceso al atestado policial antes de que su defendido prestase declaración en dependencias policiales o posteriormente cuando fuera puesto a disposición judicial, resuelta a favor de esta última, y se estableció la asistencia letrada obligatoria (de oficio) si no había designación de abogado, incluso para el investigado no detenido por la Policía judicial. La LO 5/2015, de 27 de abril, no explicitó el derecho de acceso al atestado, previo a la declaración del detenido en sede policial, sino el derecho de acceso a los elementos de las actuaciones esenciales para impugnar la legalidad de la detención o privación de la libertad [art. 520. 2. d) LECrim]. Aún a pesar de ello, tras la reforma en 2015, se produjeron algunas situaciones controvertidas entre abogados y miembros de la Policía judicial con relación a este nuevo derecho y reabrió la polémica sobre el acceso al atestado. El CGAE trasladó un protocolo de actuación en las asistencias de los abogados a los detenidos en sede policial donde indicaba la solicitud de examinar el atestado antes de su toma de declaración, salvo algunos supuestos ${ }^{38}$, pero en la práctica dicho acceso pleno no fue obtenido.

Con carácter general, no parece razonable que el abogado o el detenido tengan acceso al mismo, al menos de forma completa, porque en algunos casos ello podría poner en riesgo la investigación po-

Ley Orgánica 6/1984, de 24 de mayo, reguladora del procedimiento de Habeas Corpus (LOHC).

38 Circular REICAZ 42/2015 de 29 de octubre. https://www.reicaz.org/circubol/ circucol/2015/cc201542.htm

PROTOCOLO DE ACTUACIÓN EN ASISTENCIAS A DETENIDOS EN SEDE POLICIAL I) CON ANTERIORIDAD A LA ASISTENCIA. «2 .- Derecho del abogado a examinar los materiales del expediente policial antes de la declaración del detenido. Concretamente se solicitará examinar el atestado o diligencias policiales, salvo los siguientes supuestos: a. Que las mismas estén bajo secreto sumarial b. Que la vista de los datos de las diligencias pueda dar lugar a amenaza grave para la vida o derechos fundamentales, o para defender un interés público importante.

Ante la negativa del examen del atestado policial previo a la declaración, o cuando los motivos de ello generen dudas en el abogado, hacer constar la protesta en diligencia previa a la declaración y como parte integrante del atestado policial». 
licial y la posterior investigación judicial. En este sentido se pronunció la STS 1283/2000, de 12 de julio, que declaró que la pretensión de obtener copia de todo el atestado puede incidir negativamente en la investigación que en ese momento inicial puede afectar a otras personas $\mathrm{u}$ otros delitos. Posteriormente, el TS ha negado que este acceso comprenda las bases policiales con el fin de obtener las notas y minutas relacionadas con las declaraciones de algunos de los testigos policiales. Asimismo, el Alto Tribunal ha indicado que la fase previa a la investigación que no se vierte sobre el proceso carece de virtualidad como fuente de prueba y no integra el expediente preciso para el efectivo ejercicio de defensa ${ }^{39}$. Además, el TS recuerda que el art. 3. c) del Convenio del Consejo de Europa sobre el acceso a los documentos públicos permite limitar el acceso para proteger la prevención, la investigación y persecución de actividades criminales ${ }^{40}$.

Finalmente, la STC 21/2018, de 5 de marzo, ha negado que dicho derecho otorgue una facultad de acceso pleno al atestado ${ }^{41}$, pero el 27 de marzo de 2019, un año después, cuando nuevamente parecía que esta polémica sobre el acceso al atestado en sede policial estaba resuelta definitivamente, el Colegio de Abogados de Madrid (ICAM) ha participado por primera vez en la reunión de la Comisión Provincial de Coordinación de Policía judicial (CPCPJ). En ella el ICAM solicitó el acceso pleno del abogado al contenido del atestado con anterioridad a la toma de declaración del cliente detenido, así como que se facilite a los letrados una copia de los elementos o materiales que solicite. Dicha CPCPJ ha mostrado su acuerdo, advirtiendo de que: "en los casos que afecten a terceros o haya un proceso de in-

39 SSTS 795/2014, de 20 de noviembre y 975/2016, de 23 de diciembre. Esta última indica que: «La doctrina jurisprudencial del TEDH ha admitido la legalidad de la utilización de estas fuentes confidenciales de información, siempre que se utilicen exclusivamente como medios de investigación y no tengan acceso al proceso como prueba de cargo (Asuntos Kostovski, de 20 de noviembre de 1989 -\& 44-, o Windisch, de 27 de septiembre de 1990 -\& 30-)».

40 STS 975/2016, de 23 de diciembre. «El Convenio del Consejo de Europa sobre el Acceso a los Documentos Públicos, STCE núm. 205, hecho en Tromsø el 18 de junio de 2009, precisa la ratificación de diez Estados miembros para su entrada en vigor, cifra aún no conseguida en esa data; y España en todo caso no lo ha ratificado".

${ }^{41}$ STC 21/2018, de 5 de marzo:«.... no otorga una facultad de acceso pleno al contenido de las actuaciones policiales o judiciales practicadas con anterioridad a la detención, o como consecuencia de la misma, que se plasman en el atestado pues, más limitadamente, únicamente cobra sentido y se reconoce el acceso a aquéllas que sean esenciales para impugnar la legalidad de la detención, esto es, fundamentales o necesarias para cuestionar si la privación cautelar penal de libertad se ha producido en uno de los casos previstos en la ley o, dicho de otra forma, si la misma se apoya en razones objetivas que permitan establecer una conexión lógica entre la conducta del sospechoso y el hecho investigado, justificando así la privación de libertad». 
vestigación abierto que pudiera verse perjudicado, no será posible dar cumplimiento a esta petición $n^{42}$ ». Este acuerdo estaría justificado en la interpretación a sensu contrario de la propia argumentación de la STC 21/2018, de 5 de marzo $^{43}$. Asimismo, la FGE se ha pronunciado en similar sentido ${ }^{44}$. De ello puede inferirse que este acceso pleno al atestado en sede policial, tanto por el detenido como por su abogado, sería posible en esos determinados supuestos.

Al hilo de lo anterior surgen las siguientes preguntas: ¿Acaso la investigación policial va por un lado y la investigación judicial por otro? ¿Ambas investigaciones son independientes o por el contrario están interrelacionadas? En mi opinión, el acceso completo al atestado policial en dicha sede podría producirse si se estableciesen de forma tasada los casos en los que cupiese el secreto de las actuaciones, lo cual parece a priori muy difícil de establecer o predecir legislativa o reglamentariamente. Debe tenerse en cuenta que el contenido de un atestado como documento oficial elaborado por la Policía judicial en su actividad de investigación penal puede ser muy variada (tramitación simple o compleja), ya que las infracciones penales objeto de investigación policial pueden ser (delitos leves, menos graves o graves) y las circunstancias concurrentes pueden ser muy diferentes (un único investigado o varios, comisión in fraganti o anterior a la investigación, modus operandi diferentes, actuación de grupo u organización criminal, bandas armadas o terroristas, etc.), $\mathrm{y}$, por tanto, las diligencias que se practiquen y plasmen en él pueden variar entre unos $\mathrm{u}$ otros $\operatorname{casos}^{45}$. Ahora bien, los delitos de en-

${ }^{42}$ https://web.icam.es/actualidad/noticia/5761/El_Colegio_de_Abogados_de_Madrid_participa_por_primera_vez_en_la_reunión_de_la_Comisión_Provincial_de_ Coordinación_de_Policía_Judicial

${ }^{43}$ La STC 21/2018, de 5 de octubre, señala que:«...el atestado puede recoger más información sobre la investigación del hecho delictivo de aquella que cabe considerar esencial para justificar la detención preventiva, pues puede haber en el mismo referencias a terceras personas no detenidas, a hechos distintos que nada tienen que ver con las razones concretas de la detención, pero que son conexos con los que han dado lugar a la investigación, o a líneas de investigación iniciadas y no agotadas cuya revelación puede poner innecesariamente en entredicho el resultado de la investigación».

${ }^{44}$ La Circular de la FGE 3/2018, de 1 de junio, ha señalado que: «En cambio, aquellos extremos de las actuaciones o, en particular, del atestado, que puedan referirse a otros aspectos de la investigación que no guarden relación directa con la detención, no integrarán el derecho de información del detenido, lo que justifica que le pueda ser denegada la entrega del atestado policial en su integridad».

${ }^{45} V$. gr. Denuncia, inspecciones oculares, declaraciones de testigos o investigados, diligencias de identificación o de reconocimiento, en rueda o fuera de ella, informes periciales, informes de inteligencia policial, acta de sintomatología externa y datos obrantes sobre el modo de conducir, dictámenes o de informes dictados por gabinetes de la policía ( $v$. gr. los de dactiloscopia, identificación, análisis químicos, 
juiciamiento rápido, introducidos mediante la Ley 38/2002, de 24 de octubre (arts. 795 a 803 LECrim $^{46}$ ), por la sencillez de su investigación e instrucción, podrían servir de criterio para permitir este acceso pleno al atestado previo a la declaración del detenido en sede judicial. La investigación de estos delitos suele ser sencilla y si esta estuviera finalizada, sin terceros afectados, esto es, cuando la declaración del detenido fuese la última diligencia de investigación practicada antes del cierre del atestado, no parece que existiera inconveniente para que se permitiera dicho acceso con carácter previo, dado que este sería posible momentos después en sede judicial, una vez el detenido fuese puesto a disposición judicial. Asimismo, en estos casos la justificación de impedir el acceso pleno desaparecería, porque el secreto no sería procedente, la investigación penal no estaría en riesgo y este acceso no incidiría negativamente en su resultado. Por ello, el legislador debería ser más preciso en su regulación incorporando la reciente doctrina del TC, explicitando que en el derecho de acceso a los elementos esenciales se integra el acceso pleno al atestado por el detenido o su abogado cuando la investigación policial no afecte a terceros ni haya un proceso de investigación abierto que pudiera verse perjudicado, para evitar fututos conflictos entre los distintos operadores jurídicos.

La Autoridad judicial es el destinatario del atestado policial según la LECrim (arts. 284 y 292). En caso de duda, esta será quien decida en cada caso concreto si decreta o no el secreto de las actuaciones para los delitos públicos según el art. 302 LECrim $^{47}$, lo cual

balísticos u otros análogos), diligencias objetivas y de resultado incontestable ( $v$. $g r$. la aprehensión de los delincuentes sorprendidos «in fraganti», la constancia del cuerpo, los efectos o los instrumentos del delito, el hallazgo de droga, armas, documentos o cualquier otro objeto, los croquis sobre el terreno, las fotografías en él obtenidas y la comprobación de la alcoholemia, etc.) que encajan por definición en el concepto de la prueba preconstituída o anticipada, acta o diligencia de entrada y registro en lugar cerrado, diligencias de interceptación de las comunicaciones telefónicas y telemáticas, la captación y grabación de comunicaciones orales mediante la utilización de dispositivos electrónicos, la utilización de dispositivos técnicos de seguimiento, localización y captación de la imagen, el registro de dispositivos de almacenamiento masivo de información y los registros remotos sobre equipos informáticos, certificados médicos, etc.

$46 \mathrm{El}$ art. 795.3 LECrim dispone que: «No se aplicará este procedimiento en aquellos casos en que sea procedente acordar el secreto de las actuaciones conforme a lo establecido en el artículo 302».

47 La LO 5/2015, de 27 de abril, ha reformado el art. 302 LECrim, el cual tiene la siguiente redacción:

«Las partes personadas podrán tomar conocimiento de las actuaciones e intervenir en todas las diligencias del procedimiento.

No obstante, si el delito fuere público, podrá el Juez de Instrucción, a pro puesta del Ministerio Fiscal, de cualquiera de las partes personadas o de oficio, declararlo,

(C) UNED. Revista de Derecho UNED, núm. 27, 2021 
requiere la aplicación de un juicio de proporcionalidad para resolver el conflicto entre la investigación judicial y el derecho de defensa del investigado incurso en un procedimiento judicial. El acceso al atestado en sede policial por el detenido o su abogado de forma plena en cualquier caso no forma parte del contenido esencial del derecho del detenido a la asistencia letrada prevista en el art. 17. $3 \mathrm{CE}$, pero si lo forma el acceso a dichos elementos esenciales, dado que este se mantiene operativo en cualquier momento (preprocesal y procesal penal), estado de las actuaciones (públicas y secretas), situación procesal del detenido o preso (comunicado e incomunicado) y sede (policial, ministerio público y judicial).

\section{IV.2. Contenido y finalidad del derecho de acceso a los elementos esenciales}

La LO 5/2015, de 27 de abril, no determinó con claridad el contenido del nuevo derecho de acceso a los elementos de las actuaciones esenciales para impugnar la legalidad de la detención o privación de la libertad [art. 520. 2. d) LECrim].

La Circular de la FGE 3/2018, de 1 de junio, analiza el derecho de información de los investigados en los procesos penales y examina la información facilitada a un detenido en sede policial, teniendo en cuenta la STC 21/2018, de 5 de marzo. En este caso el recurrente había sido detenido, junto a otros jóvenes, informándole únicamente de que había sido detenido por un presunto delito de lesiones, al ser interceptados en el lugar de los hechos por efectivos actuantes, detallando el lugar y hora del presunto ilícito penal y el de la detención. A pesar de que solicitó acceso a la parte del atestado redactado, la petición fue rechazada en sede policial. La denegación de incoación del habeas corpus presentado fue recurrida en amparo y el TC concluyó como indica la FGE que: «la información facilitada no proporcionaba una base real suficiente de la que pudieran inferirse racionalmente su participación en el delito investigado y no le permitían, por insuficientes, cuestionar

mediante auto, total o parcialmente secreto para todas las partes personadas, por tiempo no superior a un mes cuando resulte necesario para:

a) evitar un riesgo grave para la vida, libertad o integridad física de otra persona; o

b) prevenir una situación que pueda comprometer de forma grave el resultado de la investigación o del proceso.

El secreto del sumario deberá alzarse necesariamente con al menos diez días de antelación a la conclusión del sumario.

Lo dispuesto en este artículo se entenderá sin perjuicio de lo previsto en el párrafo segundo del apartado 3 del artículo 505». 
fundadamente su privación de libertad, pues se omitieron datos objetivos que relacionaban a los jóvenes detenidos con la agresión y que constituían las razones objetivas de la detención». El TC estimó la pretensión de amparo al haberse vulnerado las garantías del art. 17.1 y $3 \mathrm{CE}$, "no porque en el caso concreto no existieran razones para detener al demandante, sino porque habiéndolas, las mismas no se pusieron de manifiesto al detenido o a su abogado a través de los procedimientos establecidos en la ley».

La CNCPJ, el día 3 de abril de 2017, aprobó los «Criterios para la práctica de diligencias por la Policía judicial» ${ }^{48}$, donde reiteró su acuerdo de 15 de julio de 2015 relativo al contenido de este derecho de acceso a los elementos esenciales, los que fueron recogidos por el $\mathrm{TC}^{49}$, quien indica que la determinación de cuáles sean dichos elementos esenciales es necesariamente casuística, pues dependerá de las circunstancias que justifiquen la detención y cita algunos a modo de ejemplo ${ }^{50}$.

Asimismo, el art. 3 de la Directiva 2010/64/UE, de 20 de octubre, relativa al derecho a interpretación y a traducción en los procesos penales, se prevé la forma escrita de los documentos que resulten esenciales para garantizar el ejercicio del derecho a la defensa. Su

48 Dicho Manual se ha elaborado por la CNCPJ con base a la competencia que le atribuye el art. 36.3) del Real Decreto 769/1987, de 19 de junio, sobre regulación de la Policía judicial y en el que han colaborado la FGE, la Secretaría de Estado de Justicia, la Secretaría de Estado de Seguridad, la Dirección General de la Guardia Civil, la Dirección General de la Policía, la Dirección Adjunta de Vigilancia Aduanera, la Dirección General de la Policía de la Generalitat - Mossos d'Esquadra, el Departamento de Seguridad del Gobierno Vasco, la Dirección General de Interior del Gobierno de Navarra.

49 STC 21/2018, de 5 de marzo: «En este sentido, y a ello se hace referencia acertadamente en la demanda de amparo, la Comisión Nacional de Coordinación de la Policía judicial, en su reunión de 15 de julio de 2015, vigente ya la Ley Orgánica 5/2015, de 27 de abril, fijó como contenido mínimo de la información policial que ha de facilitarse a los detenidos la que se refiere al lugar, fecha y hora de la detención y la comisión del delito, a la identificación del hecho delictivo, y también a los "indicios de los que se deduce la participación del detenido en el hecho delictivo", indicios sobre los que ha de reseñarse su procedencia objetiva».

${ }^{50}$ STC 21/2018, de 5 de marzo: «...la propia denuncia de los hechos, cuando incorpora imputaciones de parte que incriminan al detenido; o la documentación de testimonios incriminatorios, así como el contenido de los informes periciales científicos que establezcan un vínculo de conexión entre el hecho investigado y el detenido; asimismo lo pueden ser los documentos, fotografías y grabaciones de sonido o vídeo que objetivamente relacionen al sospechoso con la infracción penal, e igualmente las actas que recojan el resultado del registro de un inmueble u otro tipo de bienes (STC 13/2017, de 30 de enero, FJ 7), las de una inspección ocular, las que constatan la recogida de vestigios o las que describan el resultado de un reconocimiento practicado a prevención por la policía para la averiguación del delito. Lo son también, en definitiva, todas aquellas actuaciones documentadas que guarden identidad de razón con las ya expuestas».

(C) UNED. Revista de Derecho UNED, núm. 27, 2021 
apartado 2 dispone que: "Entre los documentos esenciales se encuentra cualquier resolución que prive a una persona de libertad, escrito de acusación y sentencia, mientras que el art. 123. 1. d) LECrim limita este derecho de traducción escrita para «la prisión del imputado, el escrito de acusación y la sentencia» ya en el procedimiento penal. Ahora bien, el nuevo art. 123 LECrim no prevé explícitamente la traducción del documento que acuerde la detención preventiva, dado que el art. 3 de la Directiva se refiere al proceso judicial, salvo en la fase preprocesal para la declaración escrita de los derechos del detenido en un lenguaje que comprenda (traducida) la cual se le permitirá conservar una copia durante el tiempo de la detención, conforme a los dos últimos incisos del art. 520. 2 LECrim ${ }^{51}$ introducidos por la transposición de la Directiva 12/13/UE, de 22 de mayo. El TJUE $^{52}$ se ha pronunciado sobre cómo debe interpretarse el art. 3 de la Directiva 2010/64, de 20 de octubre. Para GÓMEZ GUMÁN ${ }^{53} \mathrm{en}$ su análisis de las SSTJUE de los casos Covaci $^{54}$ y Sleutjes c. Alemania, indica entre otras cuestiones que habrá que estar «a la espera de que los futuros pronunciamientos del TJUE ofrezcan una posición más favorable y extensiva del derecho a la asistencia lingüística y, en especial, a la traducción de documentos esenciales».

Sobre la finalidad de este derecho de acceso, el TC pone de manifiesto el doble fundamento constitucional, esto es: «...facilitar la posibilidad de contrastar objetivamente la veracidad y consistencia de la

51 LO 5/2015, de 27 de abril. Artículo segundo. Art. 520. 2. (dos últimos incisos). "Cuando no se disponga de una declaración de derechos en una lengua que comprenda el detenido, se le informará de sus derechos por medio de un intérprete tan pronto resulte posible. En este caso, deberá entregársele, posteriormente y sin demora indebida, la declaración escrita de derechos en una lengua que comprenda.

En todos los casos se permitirá al detenido conservar en su poder la declaración escrita de derechos durante todo el tiempo de la detención»

52 STJUE, Sala Quinta, de 12 de octubre de 2017, C-278/16, caso Sleutjes c. Alemania. "El artículo 3 de la Directiva 2010/64 del Parlamento Europeo y del Consejo, de 20 de octubre de 2010, relativa al derecho a interpretación y a traducción en los procesos penales, debe interpretarse en el sentido de queun acto como una resolución prevista por el Derecho nacional para sancionar infracciones penales leves dictada por un juez tras un procedimiento unilateral abreviado constituye un "documento esencial» a los efectos del apartado 1 de dicho artículo, del cual deben recibir una traducción escrita que respete los requisitos formales que establece la referida disposición las personas sospechosas o acusadas que no comprendan la lengua del proceso de que se trate, con el fin de permitirles ejercer su derecho de defensa y de salvaguardar de este modo la equidad del proceso».

53 GÓMEZ GUZMÁN, Carmen: Las Sentencias Covaci y Sleutjes: Alcance del derecho a traducción de documentos esenciales en procesos penales en la Unión Europea, pág. 82 a 84.

${ }^{54}$ STJUE, Sala Primera, de 15 Octubre de 2015, C-216/2014, caso Covaci c. Alemania. 
información recibida y, en caso de desacuerdo, permite cuestionarla fundadamente ante la autoridad judicial. Es además relevante para decidir la estrategia que el detenido considera útil a sus intereses de defensa. Por ello, el reconocimiento legal expreso de este derecho refuerza la importancia del habeas corpus como procedimiento de control judicial de los casos y modos en que la privación de libertad es legítima» ${ }^{55}$. Además, el TC ha señalado que este derecho de acceso «...., únicamente cobra sentido y se reconoce el acceso a aquéllas que sean esenciales para impugnar la legalidad de la detención, esto es, fundamentales o necesarias para cuestionar si la privación cautelar penal de libertad se ha producido en uno de los casos previstos en la ley o, dicho de otra forma, si la misma se apoya en razones objetivas que permitan establecer una conexión lógica entre la conducta del sospechoso y el hecho investigado, justificando así la privación de libertad». En mi opinión, por medio de este derecho de acceso el detenido o su abogado pueden verificar en sede policial no solo si concurre alguno de los casos legales que justifican la detención y la forma legal de acordarla, practicarla o prolongarla (art. 17. 1 CE), o si la información proporcionada por la Policía judicial sobre los hechos atribuidos, derechos y las razones de su detención es conforme al art. 17. 3 CE y su desarrollo legal, sino también permite comprobar el cumplimiento del resto de garantías que protegen su libertad ambulatoria, tales como: si se cumplen los plazos de duración de la detención: relativo («estrictamente necesario») o absoluto («y, en todo caso, en el plazo máximo de setenta y dos horas») ex art. 17. $2 \mathrm{CE}$, o el plazo máximo para las detenciones especiales que podrá alcanzar hasta: las 24 horas para la detención de menores de edad y mayores de 14 años y para casos de extradición pasiva; cinco o tres días si fueran mayores o menores de edad respectivamente los detenidos por delitos relacionados con bandas, armadas, organizaciones o grupos terroristas; diez días durante la vigencia de los estados de excepción o sitio $^{56}$, o si procede instar el habeas corpus al considerar que se encuentra ilegalmente detenido, en virtud del art. $1 \mathrm{LOHC}^{57}$.

55 STC 21/2018, de 5 de marzo.

56 Art.17.4 LO 5/2000, de 12 de enero, reguladora de la responsabilidad penal de los menores; art. 8 Ley 4/1985, de 21 de marzo, de extradición pasiva; art. 520 bis LECrim y arts. 16.1 y 32.3 LO 4/1981, de 1 de junio, de los estados de alarma, excepción o sitio.

${ }^{57}$ LOHC. Artículo primero. A los efectos de esta ley se consideran personas ilegalmente detenidas:

a) Las que lo fueren por una autoridad, agente de la misma, funcionario público o particular, sin que concurran los supuestos legales, o sin haberse cumplido las formalidades prevenidas y requisitos exigidos por las leyes.

b) Las que estén ilícitamente internadas en cualquier establecimiento o lugar.

(C) UNED. Revista de Derecho UNED, núm. 27, 2021 


\section{IV.3. Momento y forma de ejercer el derecho de acceso a los elementos esenciales en sede policial}

Como indica FERNÁNDEZ NIETO: "La Directiva de la Unión Europea 2012/13/UE, de 22 de mayo, ha atribuido nuevos contenidos al derecho de defensa en el proceso penal español, como Estado miembro de la UE, dándose un giro de 180 grados para la efectiva protección de los derechos fundamentales contenidos en los artículo 17 y 24 de la Constitución Española, hasta el punto de que por primera vez se reclama por los distintos operadores jurídicos una Ley Orgánica para el Derecho de la Defensa, reivindicación histórica de los profesionales de la abogacía... $»^{58}$.

La defensa penal en sentido amplio acoge no solo la negación de la participación en los hechos imputados, sino también cualquier pretensión que se postule, incluso autoinculpatoria, guardar silencio, etc. La defensa penal es dual, a diferencia de la defensa civil, pues aquella está integrada por dos sujetos procesales: el abogado defensor que ejercita la defensa técnica y su defendido o imputado que puede llevar a cabo su defensa personal, privada o autodefensa, siendo aquella complementaria de esta. Como señala GIMENO SENDRA, el derecho de asistencia de letrado, previsto en el art. 24 CE, es un derecho fundamental, inalienable, instrumental y de autonomía limitada, supeditado o condicionado por la defensa privada o autodefensa. Este derecho es instrumental del más amplio derecho de defensa, garantizado tanto en las diligencias policiales como en las judiciales (arts. 17. 3 y 24. 2 CE) ${ }^{59}$. Ambas defensas (la privada o autodefensa y la defensa técnica por medio de abogado) se manifiestan coincidentes en un único objetivo: el fin de hacer valer el derecho a la libertad, por ello, ambos, detenido y su abogado, están legitimados para ejercer el nuevo derecho de acceso a los elementos esenciales para impugnar la legalidad de la detención [art. 520. 2. d) ] LECrim, incluso si se decreta el secreto del sumario o su incomunicación.

El reformado art. 302 LECrim determina los supuestos en los que podrá acordarse judicialmente el secreto de las actuaciones para las partes personadas, salvo para el Ministerio fiscal. Dicho secreto

c)Las que lo estuvieran por plazo superior al señalado en las leyes, si transcurrido el mismo, no fuesen puestas en libertad o entregadas al Juez más próximo al lugar de la detención.

d) Las privadas de libertad a quienes no les sean respetados los derechos que la Constitución y las leyes procesales garantizan a toda persona detenida».

58 FERNÁNDEZ NIETO, Josefa: El acceso a los atestados policiales: a vueltas con las garantías de defensa en el proceso penal español, pág. 41.

${ }_{59}$ GIMENO SENDRA, José Vicente: Derecho procesal penal, 1ª edición, pág. 213. 
tiene el límite que establece la nueva redacción de este precepto legal: «Lo dispuesto en este artículo se entenderá sin perjuicio de lo previsto en el párrafo segundo del apartado 3 del artículo 505». Por esto, el abogado «tendrá, en todo caso, acceso a los elementos de las actuaciones que resulten esenciales para impugnar la privación de libertad del imputado» (art. 505. 3 LECrim), esto es, el abogado tendrá este acceso a estos elementos esenciales incluso cuando se decrete el secreto de las actuaciones. Igualmente, dicho acceso a los elementos esenciales será posible también en los supuestos en los que el detenido esté incomunicado, según se desprende del art. 527. 1. d) LECrim (reformado por la LO 13/2015, de 5 de octubre), tanto para los supuestos previstos en el nuevo art. 509 como los del art. 520 bis LECrim ${ }^{60}$.

Ahora bien, el [art. 520. 2. d) LECrim] no explicita el momento temporal concreto en el que se permita dicho acceso a los elementos esenciales, aunque lógicamente esta garantía intervendrá durante la detención y antes del interrogatorio del detenido ${ }^{61}$. En relación con su ejercicio, este acceso debe ser solicitado expresamente, bien por el detenido, bien por su abogado a los agentes policiales, dado que no se explicita su ejercicio de oficio. Dicho derecho de acceso está configurado de forma similar a otros derechos del detenido o preso ( $v$. gr. derecho de reconocimiento médico, derecho de puesta en conocimiento de familiar o persona que designe), esto es, se trata de un derecho disponible por dichos sujetos, de tal forma que pueden o no ejercer dicho acceso. Si cualquiera de ellos lo solicitan se «...estará en condiciones de contrastar su veracidad y suficiencia. Tal constatación permite identificar el fundamento, momento, forma y contenido del derecho de acceso...».

Como indica el $\mathrm{TC}^{62}$, este acceso debe producirse de forma efectiva, «mediante exhibición, entrega de copia o cualquier otro método que, garantizando la integridad de las actuaciones, permita al detenido conocer y comprobar por sí, o a través de su letrado, las

${ }^{60}$ Supuestos de detención o prisión incomunicada (art. 509 LECrim) y detención por delito cometido por persona integrada o relacionada con bandas armadas o individuos terroristas o rebeldes, previsto en el art. 384 bis (art. 520 bis LECrim).

${ }^{61}$ En el art. 7 de la Directiva 2012/13/CE, de 22 de mayo, se introduce un plazo relativo y otro absoluto para hacer efectivo dicho acceso, esto es, el primero se produciría "con la debida antelación que permita el ejercicio efectivo de los derechos de la defensa»; y el segundo plazo "a más tardar en el momento en que los motivos de la acusación se presenten a la consideración del Tribunal». Asimismo, el primer plazo seguirá operativo igualmente "Si llegan a poder de las Autoridades competentes más pruebas materiales, ...para que puedan ser estudiadas».

62 STC 21/2018, de 5 de marzo. 
bases objetivas de su privación de libertad. En caso de discrepancia con los agentes policiales sobre qué elementos de las actuaciones son esenciales en el caso concreto, el detenido o su abogado podrían activar la garantía del habeas corpus para que la Autoridad judicial dirima la controversia».

A priori y con carácter general, una diligencia policial específica que informe sobre los hechos atribuidos, concretados espacial y temporalmente, derechos que le asisten, precepto/s infringido/s e indicios racionales de su presunta participación en los mismos, $v$. gr. impresión dactilar, grabación, reconocimiento fotográfico, testifical, documental, etc., podría ser suficiente para que este derecho de información fuera real y efectivo. Otra solución podría consistir en la constancia de esa triple información en la misma diligencia o acta de detención e información de derechos que se extiende al detenido en dependencias policiales. Actualmente, en la práctica policial, siguiendo las instrucciones de la CNCPJ y de la Secretaria de Estado de Seguridad, la Policía judicial sigue la segunda opción con carácter general, pero cualquiera de las dos podría ser válida. Sobre los supuestos particulares de detención, $v$. gr. a los requisitoriados deberían ser informados del contenido de la correspondiente resolución judicial y si la detención estuviera motivada por el cumplimiento de una orden europea de detención (OED) o internacional de detención (OID) debería informarse del contenido de la misma. Asimismo, ante detenciones con solicitud o acuerdo de diligencias secretas, incomunicación o protección de testigo, la Policía judicial debería consultar a la Autoridad judicial sobre el alcance de los elementos esenciales a acceder ${ }^{63}$.

Con la reforma de la LECrim, mediante la LO 13/2015, de 5 de octubre, la participación activa del abogado en sede policial ha aumentado (art. 520. 6) ${ }^{64}$ y se ha modificado el art. 520. 2 c) LECrim

63 La CNCPJ en sesión de 3 de abril de 2017, aprobó los «Criterios para la práctica de diligencias por la Policía judicial». En él se alude a estos como casos particulares (requisitoriado, detenidos en cumplimiento de una OEDE, o una OID).

64 Art. 520 LECrim «6. La asistencia del abogado consistirá en:

a) Solicitar, en su caso, que se informe al detenido o preso de los derechos establecidos en el apartado 2 y que se proceda, si fuera necesario, al reconocimiento médico señalado en su letra i).

b) Intervenir en las diligencias de declaración del detenido, en las diligencias de reconocimiento de que sea objeto y en las de reconstrucción de los hechos en que participe el detenido. El abogado podrá solicitar al juez o funcionario que hubiesen practicado la diligencia en la que haya intervenido, una vez terminada ésta, la declaración o ampliación de los extremos que considere convenientes, así como la consignación en el acta de cualquier incidencia que haya tenido lugar durante su práctica. 
que refuerza la garantía de asistencia de abogado al detenido mediante la comunicación telefónica o videoconferencia con el detenido en el supuesto de que dicha asistencia presencial no sea posible realizarla por la lejanía geográfica ${ }^{65}$. Por tanto, el ejercicio de este derecho de acceso, la entrevista previa reservada y el resto de derechos del detenido, que sean compatibles con la prestación a distancia de este servicio, deberían respetarse del mismo modo que en un servicio presencial mediante la utilización de dichos medios técnicos, pero teniendo cuenta las limitaciones que se puedan derivar durante su ejercicio ( $v . g r$. estado de conexión a internet).

\section{4. GARANTÍAS CONSTITUCIONALES AFECTADAS}

De la doble finalidad constitucional puesta de manifiesto por la STC 21/2018, de 5 de marzo, podemos inferir que este derecho de acceso [art. 520. 2. d) LECrim] conlleva un reforzamiento de las garantías del detenido y afecta a: los casos y la forma legal que justifican la detención (art. 17. 1 CE), la garantía temporal (art. 17. $2 \mathrm{CE}$ ), la de información de los derechos y las razones de la detención, autodefensa y defensa técnica (art. 17. 3 y 24. 2 CE) desarrolladas en el art. 520. 2 LECrim y la garantía de habeas corpus (art. 17. 4 CE). Dicho derecho de acceso complementa esta última pero no la sustituye, dado que el habeas corpus no exige su ejercicio previo para instarlo.

Ahora bien, no olvidemos que este derecho de acceso refuerza a posteriori la garantía casos legales que justifican la detención, dado que esta actua ex ante, esto es, antes de practicar la detención. Hipotéticamente podrían concurrir los casos legales que justifican la detención policial, pero que los agentes policiales no informasen

c) Informar al detenido de las consecuencias de la prestación o denegación de consentimiento a la práctica de diligencias que se le soliciten.

Si el detenido se opusiera a la recogida de las muestras mediante frotis bucal, conforme a las previsiones de la Ley Orgánica 10/2007, de 8 de octubre, reguladora de la base de datos policial sobre identificadores obtenidos a partir del ADN, el juez de instrucción, a instancia de la Policía Judicial o del Ministerio Fiscal, podrá imponer la ejecución forzosa de tal diligencia mediante el recurso a las medidas coactivas mínimas indispensables, que deberán ser proporcionadas a las circunstancias del caso y respetuosas con su dignidad.

d) Entrevistarse reservadamente con el detenido, incluso antes de que se le reciba declaración por la policía, el fiscal o la autoridad judicial, sin perjuicio de lo dispuesto en el artículo $527 »$.

65 Art. 520. 2 c) LECrim:«En caso de que, debido a la lejanía geográfica no sea posible de inmediato la asistencia de letrado, se facilitará al detenido comunicación telefónica o por videoconferencia con aquél, salvo que dicha comunicación sea imposible». 
correctamente de las razones motivadoras. Al revés esto no parece posible, dado que si no concurriera el caso legal habilitante para la detención la información proporcionada sobre las razones que motivan la detención sería incorrecta, lo cual podría afectar negativamente en su autodefensa o defensa técnica y también afectaría a la garantía temporal, debiendo provocar la solicitud de acceso a los elementos esenciales y, en su caso, al habeas corpus.

Asimismo, resulta acertado el reconocimiento del derecho de acceso tanto para el detenido como para su abogado, pero la reforma de la LECrim en 2015 se olvida de haber incluido al abogado del detenido como legitimado para instar el habeas corpus (art. 3 LOHC), tal y como lo ha reconocido el $\mathrm{TC}^{66}$ y propuso el informe jurídico de la Comisión del $\mathrm{CGAE}^{67}$. Asimismo, este derecho del detenido a instar el habeas corpus sigue sin incluirse en el catálogo de sus derechos ex art. 520 LECrim; no obstante, la Instrucción 12/2007, de 14 de septiembre, de la Secretaría de Estado de Seguridad, lo introdujo en la práctica policial ${ }^{68}$. Por otra parte, parece que lo lógico sería que, antes de instar el habeas corpus, el detenido o su abogado hubieran accedido a los elementos esenciales para impugnar la legalidad de la detención, o al menos haberlo solicitado sin conseguirlo. Ahora bien, de cualquier forma, accedan o no a dichos elementos esenciales, cualquiera de ellos podrían solicitar el habeas corpus para impugnar la legalidad de la detención policial antes de que fuera puesto a disposición judicial. Una vez el detenido sea puesto a disposición judicial, no podrá instarse el habeas corpus, aunque su abogado podrá impugnar la privación de libertad de su cliente ex art. 505. 3 LECrim.

En todos estos casos, el abogado del detenido en sede policial deberá valorar la información esencial suministrada por la Policía judicial para impugnar la legalidad de la detención (habeas corpus) o por la Autoridad judicial para impugnar en sede judicial la privación de libertad (solicitar su nulidad a efectos procesales). Por el contrario, el abogado no tendrá acceso pleno al atestado policial ni al resto del expediente judicial (diligencias previas, etc.) si hubieran sido de-

${ }^{66}$ ATC 55/1996, de 6 de marzo, STC 224/1998, de 24 de noviembre; entre otras.

${ }^{67}$ Informe jurídico 6/2015, de la Comisión del CGAE, págs. 51 a 64.

68 Instrucción 12/2007, de 14 de septiembre, de la Secretaría de Estado de Seguridad, sobre los comportamientos exigidos a los miembros de las Fuerzas y Cuerpos de Seguridad del Estado para garantizar los derechos de las personas detenidas o bajo custodia policial. Tercera: Derechos de Detenido: 3.«También se le informará de su derecho constitucional a solicitar el habeas corpus, si considera que su detención no está justificada legalmente, o que transcurre en condiciones ilegales, facilitándole al efecto el impreso de solicitud que se acompaña como anexo». 
claradas secretas, salvo el acceso a los elementos esenciales para impugnar la legalidad de la detención o la privación de la libertad, cuyo cumplimiento deberá velar el Ministerio fiscal ${ }^{69}$. Por todo ello, el contenido de este derecho de acceso [art. 520. 2. d) LECrim] forma parte del contenido esencial del derecho de autodefensa y defensa técnica del detenido, de tal forma que debe ser respetado conforme establece el art. 53. 1 CE.

\section{CONCLUSIONES}

El derecho de acceso a los elementos esenciales por el detenido y su abogado es la garantía que más controversias ha producido entre los operadores jurídicos, dado que se trata de un concepto jurídico indeterminado y reabre la polémica sobre el acceso al atestado en sede policial, inicialmente zanjada con la Ley 38/2002, de 24 de octubre. La STC 21/2018, de 5 de marzo, determina que este acceso no es pleno, sino limitado a aquellas que sean esenciales para impugnar la legalidad de la detención, esto es, fundamentales o necesarias para cuestionar si la privación cautelar penal de la libertad se ha producido en uno de los casos previstos en la ley. Ahora bien, un año después la CPCPJ de Madrid ha mostrado conformidad con la petición del ICAM de acceder al atestado, salvo: «en los casos que afecten a terceros o haya un proceso de investigación abierto que pudiera verse perjudicado». Los delitos de enjuiciamiento rápido, introducidos mediante la Ley 38/2002, de 24 de octubre, por la sencillez de su investigación e instrucción, podrían servir de criterio para permitir el acceso pleno al atestado previo a la declaración del detenido en sede policial, siempre y cuando se respetase la reciente doctrina del TC.

Este derecho de acceso a los elementos esenciales en sede policial debe ser solicitado expresamente por el detenido o su abogado, dado que no se prevé su ejercicio de oficio y debe ejercerse siempre antes de que haya finalizado la redacción del atestado. Este acceso tiene doble apoyo constitucional según el TC, esto es, comprobar la lega-

${ }^{69}$ La conclusión número $13^{\text {a }}$ de la Circular de la FGE 3/2018, de 1 de junio, señala que: "En los casos en los que estuviera declarado el secreto de las actuaciones, los Sres. Fiscales deberán también velar por que se le facilite al privado de libertad el acceso a aquellos elementos de las actuaciones que resulten esenciales para impugnar su privación de libertad con carácter previo a la comparecencia prevista en el art. $505 \mathrm{LE}$ Crim y en los términos expuestos en la presente Circular. El acceso debe producirse de forma efectiva, mediante exhibición, entrega de copia o cualquier otro método que, garantizando la integridad de las actuaciones, permita al investigado conocer y comprobar por sí, o a través de su letrado, los elementos esenciales para impugnar la privación de libertad». 
lidad de la detención y en su caso impugnarla, y decidir la estrategia de autodefensa o defensa técnica a seguir previa a su declaración o guardar silencio ante la Policía judicial y posteriormente ante la Autoridad judicial. Sobre la comprobación de la legalidad de la detención, el detenido o su abogado, por medio de este derecho de acceso, pueden verificar en sede policial no solo si concurre alguno de los casos legales que justifican la detención (si estaba indicada o si por el contrario era procedente la toma de declaración como investigado no detenido) y la forma legal de acordarla, practicarla o prolongarla (art. 17. $1 \mathrm{CE}$ ), o si la información proporcionada por la Policía judicial sobre los hechos atribuidos, derechos y las razones de su detención es conforme al art. 17. $3 \mathrm{CE}$ y su desarrollo legal, sino también permite comprobar el cumplimiento de otras de garantías que protegen su libertad ambulatoria, tales como la garantía temporal (art. 17. $2 \mathrm{CE}$ ) o si procede instar el habeas corpus (art.17. $4 \mathrm{CE}$ ).

$\mathrm{El}$ acceso a los elementos de las actuaciones esenciales para impugnar la legalidad de la detención forma parte del contenido esencial del derecho de autodefensa del detenido y asistencia de abogado al detenido policial (art. 17. $3 \mathrm{CE}$ ) y al investigado judicial (art. 24. 2 $\mathrm{CE}$ ), ya que se mantiene operativo e intacto incluso en los supuestos en los que la Autoridad judicial decrete su incomunicación o el secreto de las actuaciones.

Ni la CE ni las últimas reformas de la LECrim en 2015 delimitan el contenido de las razones motivadoras de la detención policial, aunque el TC lo ha fijado al analizar el nuevo derecho de acceso a los elementos esenciales que ayuda a su verificación [(art. 520.2. d) LECrim]. Este triple contenido del derecho de información del detenido o del privado de libertad debe conectarse con los presupuestos que justifican la detención (art. 492 LECrim, para las detenciones practicadas por la autoridad o agente de la Policía judicial), esto es, la garantía "casos legales que justifican la detención» y, con el derecho de defensa del detenido (autodefensa y defensa técnica), dada la conexión o relación existente entre ellas. La concreción de los elementos esenciales será casuística, debiendo atender a las circunstancias de cada caso.

La actual configuración legal del detenido como investigado policial y la regulación de la figura preprocesal (investigado policial no detenido) no favorecen la labor integradora e interpretativa de la actuación de la Policía judicial en uno u otro caso, por lo que de lege ferenda el legislador debería establecer unos criterios claros que permitan determinarla a priori, para evitar la lesión de la garantía «casos legales que justifican la detención», dado que esta interviene ex 
ante, esto es, en el momento de acordar dicha medida preventiva, mientras que el derecho de acceso a los elementos esenciales para impugnar la detención opera a posteriori, esto es, una vez acordada y practicada esta.

El legislador debería explicitar que la copia escrita que debe entregarse al detenido penal se extendiese al triple contenido de la garantía constitucional de información desarrollada en el art. 520. 2 LECrim, esto es, "...hechos atribuidos, razones de su detención y derechos que le asisten,...» y no solo a estos últimos como podría desprenderse de la literalidad del último inciso del art. 520. 2 LECrim, aunque la habitual práctica policial sea más favorable a este derecho fundamental y subsane o palie dicho defecto técnico.

La reforma de la LECrim en 2015 sigue sin reconocer al abogado del detenido como legitimado activo para instar el habeas corpus, dado que tampoco ha modificado el art. 3 de la LOHC, aún a pesar de haberlo reconocido el TC. Igualmente, el habeas corpus no se encuentra en el catálogo de derechos del detenido (art. 520 LECrim), aunque es un acierto que tanto este como su abogado tengan este nuevo derecho de acceso a los elementos esenciales para impugnar su legalidad, dado su doble fundamento constitucional.

\section{BIBLIOGRAFÍA*}

CARretero SÁnchez, Adolfo: El verdadero sentido de la detención penal, Diario La Ley, nº 6834, Madrid, 2007.

COMISIÓN JURÍDICA DEL CONSEJO GENERAL LA ABOGACÍA ESPAÑOLA: Informe jurídico 6/2015, Tirant lo blanch,Valencia, 2016.

COMISIÓN NACIONAL DE COORDINACIÓN DE POLICÍA JUDICIAL: Criterios para la práctica de diligencias por la policía judicial, aprobado el 3 de abril de 2017.

De Hoyos Sancho, Montserrat: La detención por delito, Aranzadi, Pamplona, 1998.

Díez Picazo Jiménez, Luis María: Sistema de Derechos Fundamentales, Thomson Civitas, $1^{\text {a }}$ edición, Madrid, 2003.

FERNÁNDEZ NIETO, Josefa: El acceso a los atestados policiales: a vueltas con las garantías de defensa en el proceso penal español, Aletheia, Cuadernos Críticos del Derecho. 2-2018. 
FISCALÍA GENERAL DEL ESTADO: Circular 3/2018, de 1 de junio, sobre el derecho de información de los investigados en los procesos penales.

García Morillo, JoAquín: El derecho a la libertad personal (detención, privación y restricción de libertad), Tirant lo Blanch, Valencia, 1995.

Gimeno Sendra, Vicente. Derecho procesal penal. $2^{\mathrm{a}}$ edición, Colex , Madrid, 2004.

Gimeno Sendra, José Vicente / Moreno Catena, Víctor / Almagro Nosete, José / Cortés Domínguez, Valentín: Derecho Procesal, Tomo II, Proceso Penal, $4^{a}$ edición, Tirant lo Blanch, Valencia, 1992.

Gómez Guzmán, CARMen: Las Sentencias Covaci y Sleutjes: Alcance del derecho a traducción de documentos esenciales en procesos penales en la Unión Europea, Revista de Llengua i Dret, Journal of Language and Law, 2018.

Magro SERVET, Vicente: La necesaria nueva regulación de las intervenciones telefónicas a raíz de la jurisprudencia del TEDH, TC y TS, La Ley, $\mathrm{N}^{\circ}$ 6145, Sección Doctrina, 13 diciembre de 2004, Año XXV, Ref. D-251.

Martínez Pardo, Vicente José: La detención y el internamiento de extranjeros, Servicio de publicaciones, Universidad de Valencia, 2005.

SECRETARÍA DE ESTADO DE SEGURIDAD: Instrucción 12/2007, de 14 de septiembre, de la Secretaría de Estado de Seguridad, sobre los comportamientos exigidos a los miembros de las Fuerzas y Cuerpos de Seguridad del Estado para garantizar los derechos de las personas detenidas o bajo custodia policial.

https://web.icam.es/actualidad/noticia/5761/El_Colegio_de_Abogados_de_Madrid_participa_por_primera_vez_en_la_reunión_de_la_ Comisión_Provincial_de_Coordinación_de_Policía_Judicial

https://www.reicaz.org/circubol/circucol/2015/cc201542.htm

\section{JURISPRUDENCIA*}

TRIBUNAL EUROPEO DE DERECHOS HUMANOS

STEDH de 8 de junio de 1976, caso Engel y otros c. Holanda 
STEDH de 30 de agosto de 1990, caso Fox, Campbell and Hartley c. Reino Unido

STEDH de 28 de octubre de 1994, caso Murray c. Reino Unido

STEDH, Gran Sala, de 9 de julio de 2009, caso Mooren c. Alemania

TRIBUNAL DE JUSTICIA DE LA UNIÓN EUROPEA

STJUE, Sala Quinta, de 12 de octubre de 2017, C-278/16, caso Sleutjes c. Alemania

STJUE, Sala Primera, de 15 Octubre de 2015, C-216/2014, caso Covaci c. Alemania

TRIBUNAL CONSTITUCIONAL

STC 21/2018, de 5 de marzo

STC 13/2017, de 30 de enero

STC 224/1998, de 24 de noviembre

STC 21/1997, de 10 febrero

STC 21/1996, de 12 de febrero

STC 66/1996, de 16 de abril

STC 86/1996, de 21 de mayo

STC 120/1990, de 27 de junio

STC 196/1987, de 11 de diciembre

STC 252/1994, de 19 de septiembre

ATC 55/1996, de 6 de marzo

TRIBUNAL SUPREMO

STS 975/2016, de 23 de diciembre

STS 795/2014, de 20 de noviembre

STS 61/2011, de 17 de febrero

STS 10/2010, de 28 de enero

STS $1283 / 2000$, de 12 de julio

STS 6938/1996, de 5 de diciembre 
